\title{
The Effectiveness of Using Interactive CD Media on Continental Cake Processing to Improve Learning Outcomes of Course Participants in Culinary
}

\author{
Sachriani ${ }^{1}$, Rusilanti dan², and Mutiara Dahlia² \\ ${ }^{1}$ Food Service Industry Study Program, Faculty of Engineering, State University of Jakarta \\ ${ }^{2}$ Culinary Arts Vocational Education Study Program, Faculty of Engineering, State University of \\ Jakarta
}

\section{Abstract}

This study analyzes the effectiveness of using interactive CD media on continental cake processing to improve learning outcomes of course participants in culinary. The research was carried out at Pusat Pelatihan Kerja Daerah (PPKD) of Vocational Training Center majoring in culinary art consisting of South Jakarta, East Jakarta, West Jakarta, and Central Jakarta. The research used was quasi-experimental. Improved learning outcomes before and after using interactive $C D$ media on continental cake processing of course participants obtained $<\mathrm{g}>$ of 0.769 and categorized as high. Improved learning outcomes in the control group using handout media obtained 0.649 and categorized as a medium. Effectiveness testing applied by handout media in the control group of the course participants' showed the post-test value of $70 \%$ and categorized as ineffective scale. Effectiveness testing applied by interactive CD media and videos in the experimental group of the course participants showed the post-test value of $85 \%$ and categorized as effective scale. $F$-test analysis showed the value of 5.513 , while the Ftable value is 2.27 . Then $F$-count $>F$-table, Ho is rejected. It means that there are differences in group learning outcomes using conventional learning media and interactive $C D$. In conclusion, the learning continental cake processing using interactive $C D$ is more effective than handout media.

Keywords: effectiveness, implementation, interactive CD media, continental cake processing, improvement, learning outcomes, course participant, culinary art
Selection and Peer-review under the responsibility of the $3 \mathrm{rd}$ ICTVET 2018 Conference Committee.

\section{G OPEN ACCESS}

\section{Introduction}

The World Economic Forum (WEF) released the 2016 Global Competitiveness Report showing that Indonesia's overall competitiveness ranking (Basic Requirement, Efficiency Enhancer, Innovation \& Communication Factors) declined to rank 41 from the rank of 37 in the world. Indonesia ranks 100th, which is included in the low category in the 
pillar of health and primary education [1]. This is one proof that Indonesia's resources need quality improvement to be able to compete in the global era. Indonesia's human resources are closely related to the quality of education of Indonesian educational institutions. From a number of data from the Ministry of Education and Culture in the last period, shows that Indonesian education has a quality that is not yet standard. As many as $75 \%$ of schools in Indonesia do not meet the minimum education service standards, the average competency value of Indonesian teachers is 44.5 from teacher standards 75 , ranked 40 out of 40 countries in mapping the quality of education according to the Learning Curve, ranked 64 out of 65 countries according to the 2012 Program for International Study Assessment (PISA), and the world's 103rd ranking of countries whose world of education is characterized by bribery [2].

One effort that can be done to empower the community is through non-formal education institutions. Non-formal education is alternative education after formal education. Institute for Training and Education (LKP) is a form of Non-formal Education Unit that is organized for people who need knowledge, skills, life skills, and self-development, professional development, work, independent business, and/or continuing higher education. The implementation of courses and training is very strategic in an effort to support the government in realizing smart and competitive Indonesian people and helping alleviate poverty and unemployment [3]. PPKD DKI Jakarta is a Non-formal Education institution engaged in several fields of expertise, one of which is the field of Catering. PPKD in the department has printed alumni - alumni who are spread in various sectors of food, shipping, entrepreneurial catering, cafes, restaurants, and so on. But it is constrained by the use of media in learning to make it easier for participants to receive the material provided.

Learning is help provided by educators so that students can gain knowledge and change attitudes and behavior. It said that learning is a process to help students to learn well [4]. Along with the rapid development of technologies such as the internet and computers, the attractiveness of print media such as text and images reduced. The development of instructional media becomes a new learning media that is technologically interesting to students [5]. The use of interactive CD can bridge the differences in competencies and learning styles of students. It can activate all the senses that students have so that learning will be more optimal, and enjoyable. In reality, the implementation of learning has not yet utilized the media in a variety of ways. The teaching is still monotonous and has not utilized the progress of information and communication technology development. Due to many factors includes lack of an interactive CD based on 
IT in vocational learning. Facilities and infrastructure for learning using IT are available [6].

The use of appropriate learning media is an effort so that students get a concrete picture of the concept that must be understood. One of the learning media that can help students in the learning process is interactive multimedia. Rasimin et al. states that multimedia is a combination of various media in the form of text, images, graphics, sound, animation, videos, interactions, etc. which are packaged into digital files (computerized) that are delivered to the public [7]. Eristi which describes one of the multimedia mode technology applications that effectively uses helper instruction is an interactive learning $C D$ [8]. Interactive learning CDs use effective designs that include text, sound, images, photos, illustrations, animations, videos and more. Interactive CD design is built on the principle of user-centered instruction. One of the advantages of using interactive multimedia is that it can increase the attractiveness and attention of students. With this interactive multimedia learning can take place in an interesting and increasing student learning motivation [9]. In addition, Frey also explained that multimedia learning allows for a level of interactivity that can improve both text online and classroom learning based on traditional learning, and grow at all levels of education [10].

Continental Pastry Cake Processing includes: (1) Describing the meaning of continental cakes; (2) Making fillers and cake coverings from buttercream, royal icing, and chocolate; (3) Making cake, gateaux and torten; (4) Making pastry cake products from liquid dough; (5) Making pastry cake products from solid dough; (5) Using equipment for processing continental cakes; (7) Arranging and serving various continental pastries. In this study, educators have not yet used multimedia learning. Based on need analysis of students, it shows that there are some CD which shows about making various pastry products and how to make pastry products. However, this $C D$ does not meet the criteria for learning and not interactive [11]. Thus, the use of interactive multimedia learning expected to make learning more exciting and more enjoyable. So, the learning outcomes of Continental Pastry Cake Processing will be better.

\section{Methods and Equipment}

\subsection{Methods}

This study analyzes the effectiveness of using interactive CD media on continental cake processing to improve learning outcomes of course participants in culinary. Research conducted on course participants in 4 Pusat Pelatihan Kerja Daerah (PPKD) consisting 
of East Jakarta, South Jakarta, West Jakarta, and Central Jakarta. The research method used Quasi-Experiment. The difference result between pretest and posttest shows the results of the treatment given.

\subsection{Equipment}

\subsubsection{Test requirements}

A homogeneity test used to determine a sample of a population of two homogeneous classes. F-test used to test the homogeneity of the group. The testing criteria for both sample groups are said to be homogeneous if Fcount < Ftable for error level $\alpha=0.05$. Data normality test used to determine whether the data to analyze with parametric statistics which is normally distributed or not. Normality testing in this study used Liliefors test.

\subsubsection{Hypothesis test}

Hypothesis test carried out using F-test (Independent Sample Test). This test will assist by using the SPSS 16 to facilitate the analysis process. Criteria for acceptance or rejection of $\mathrm{Ho}$ at a significance level of $5 \%$ can be seen through the price of the count in the table. If the price of $F$ is higher than the specified error level (price of tcount> table), $\mathrm{Ho}$ is rejected, and $\mathrm{Ha}$ is accepted. If the price of $F$ is calculated < Ftable, $\mathrm{Ho}$ is accepted, and $\mathrm{Ha}$ is rejected.

\subsubsection{Data analysis result of effectiveness test}

Improved learning outcomes and activities are seen through increased learning activities and student learning outcomes. It calculated using normalized average gain formula. The size of factor $\langle\mathrm{g}\rangle$ is categorized as follows:

(g) $\geq 0,7$ : high improvement; 0,3 $\leq$ (g) < 0,7: medium improvement; (g) < 0,3: low improvement [12].

In determining the effectiveness of learning media, it is seen from the measurement of data results and assessment through observation. If a target is not by a predetermined time, it is not effective. Interval effectiveness scale can be seen in Figure 1 [13]. 


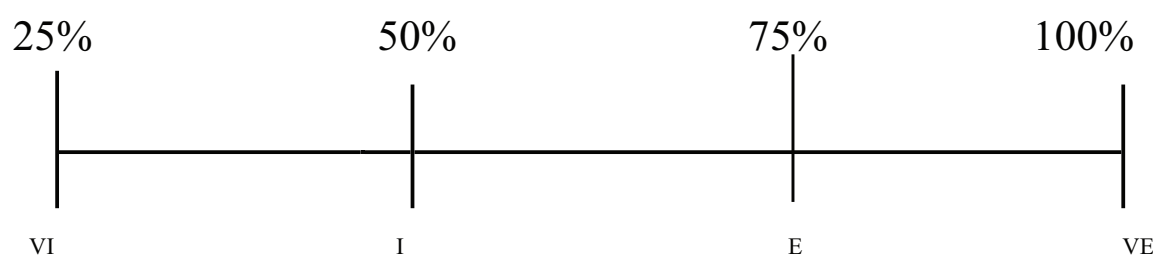

Figure 1: Interval Effectiveness Scale. (Information: VE: Very Effective E: Effective I: Ineffective VI: Very Ineffective.)

\section{Results}

A result of the gender characteristics of respondents showed: (a) In PPKD South Jakarta, there are 19 respondents with 17 female participants (89\%) and 2 male participants (11\%). (b) In PPKD East Jakarta, there are 14 respondents with 8 female participants (57\%) and 6 male participants (43\%). (c) In PPKD West Jakarta, there are 20 respondents with 16 female participants (80\%) and 4 male participants (20\%). (d) In PPKD Central Jakarta, there are 18 respondents with 16 female participants (89\%) and 2 male participants (20\%). The total number of respondents in each region was 71 participants with 57 female participants (80\%) and 14 male participants (20\%). The age characteristics showed that from 71 respondents from PPKD all of Jakarta respondents with age range 17-23 years amounted to 39 people with a percentage of 55\%, respondents aged 24-30 years amounted to 12 people with a percentage of $17 \%$, respondents with age 31 - 37 years totaling 7 people with a percentage of $10 \%$, respondents with ages 38 - 44 years amounted to 7 people with a percentage of 10\%, respondents with ages 45 - 51 years amounted to 4 people with a percentage of $6 \%$ and respondents aged 52 - 59 years totaled 2 people with a percentage of $3 \%$.

\subsection{Data description of learning outcomes achievement}

Basic knowledge of students can be seen from the learning outcomes of students before the learning (pre-test) of each study group. The average pre-test score in PPKD South Jakarta is 45 , the median of 45 and mode of 40 . The average pre-test score in PPKD Central Jakarta is 40.28, the median of 40 and modes of 35, 40, 45 and 55. The average pre-test score in PPKD East Jakarta is 52.86; the median is 55 and mode of 55. The average pre-test score in PPKD West Jakarta is 43.75, the median of 40 and mode of 35. In the post-test, there are differences in scores of each group. The post-test average score in PPKD South Jakarta is 72.11, the median of 75 and mode of 60, 65, 75 and 80. The post-test average score in PPKD Central Jakarta is 67.22, the median of 70 and mode of 75 , The post-test average score in PPKD East Jakarta is 
73.93, the median of 75 and mode of 65 and 75. The post-test average score in PPKD West Jakarta is 75.5, the median of 77.5 and mode of 85 . From the average scores, there is an increase in each class. Each improvement score both pre-test and post-test can be seen in Figure 2.

100

50

0

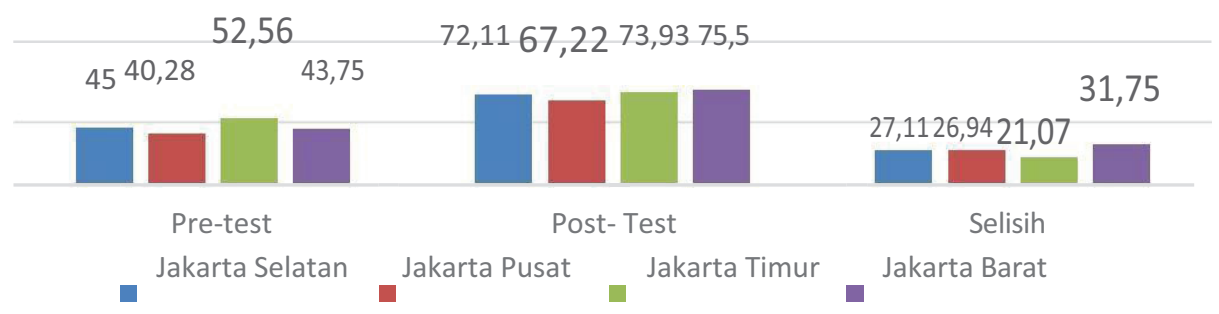

Figure 2: Chart of Average Difference in Learning Groups.

\subsection{Normality test}

The normality test used Liliefors test. The hypothesis in the normality test, Ho: the learning outcomes of students in all classes are normally distributed, Hi: the learning outcomes of students in all classes are not normally distributed. Ho is accepted if $\mathrm{Lo}_{\text {count }}$ $<\mathrm{LO}_{\text {table }}$. Based on the data normality test, the learning outcomes students of PPKD South Jakarta get Lo of 0.1196 , an average of 21.11 and standard deviation of 13.57. The number of participants is $\mathrm{n}=19$ with $\alpha ; 0.05$. It obtained $\mathrm{Lo}_{\text {table }}$ of 0.195 , where the value of $\mathrm{Lo}_{\text {count }}$ is smaller than $\mathrm{Lo}_{\text {table }}$. The learning outcomes students of PPKD Central Jakarta get Lo of 0.1213 , an average of 26.94 and standard deviation of 11.26. The number of participants is $\mathrm{n}=18$ with $\alpha ; 0.05$. It obtained $\mathrm{Lo}_{\text {table }}$ of 0.2 , where the value of $\mathrm{Lo}_{\text {count }}$ is smaller than $\mathrm{Lo}_{\text {table }}$. The learning outcomes students of PPKD East Jakarta get Lo of 0.1564 , an average of 21.07 and standard deviation of 11.96. The number of participants is $\mathrm{n}=14$ with $\alpha$; 0.05. It obtained $\mathrm{Lo}_{\text {table }}$ of 0.227 , where the value of $\mathrm{Lo}_{\text {count }}$ is smaller than $\mathrm{Lo}_{\text {table. }}$ The learning outcomes students of PPKD West Jakarta get Lo of 0.0915, an average of 31.75 and standard deviation of 13.5. The number of participants is $n=20$ with $\alpha ; 0.05$. It obtained $\mathrm{Lo}_{\text {table }}$ of 0.19 , where the value of $\mathrm{Lo}_{\text {count }}$ is smaller than Lotable.

\subsection{Homogeneity test}

The test used a Barlett test. Homogeneity is seen by comparing the chicount value with the chitablevalue with a significant level of $\alpha: 0.05$. The hypothesis in the homogeneity test is Ho: the data of all samples are homogeneous, and Hi: the data of all samples is not homogeneous. Ho is accepted if Chicount $<$ Chitable. The combined log variance 
value of all classes is 2.207 , with B value of 147.88 . The Chicount value of 1.40 and Chi table values are 7.82. Based on Chicount $<$ Chitable, Ho is accepted. It concluded that the learning outcomes of all classes are homogeneous.

\subsection{Improvement test of course participants' learning outcome}

Improved learning outcomes are seen through improved results before and after the application of interactive CD media about continental cake processing in course participants. It calculated by using normalized average $\mathrm{N}$-Gain formulas. The result of $\langle\mathrm{g}\rangle$ value is 0.769 . It means that the learning outcomes improvement of continental cake processing in the experimental class by using interactive CD media categorized as high. The learning outcomes in the control group by using media handouts amounted to 0.649 so that the assessment of improvement before and after using the media categorized as a medium.

\subsection{Data analysis of Effectiveness test result}

A pre-test value in an experimental class by not using interactive CD media obtained $48 \%$. From the interval scale [13], the pre-test data value is $48 \%$ with a Very Ineffective scale. The post-test value in an experimental class by using interactive $C D$ media obtained $85 \%$ with Effective scale. A pre-test value in control class by not using handout media obtained $43 \%$ with Very Ineffective scale. The post- test value in control class by not using handout media obtained $70 \%$ with Ineffective scale. Thus, an effectiveness analysis of using interactive $C D$ media on continental cake processing is more effective than using handout media to improve the learning outcomes of course participants.

\subsection{Hypothesis test}

Fcount value is 5.513, while the Ftable value is 2.27 . Then Fcount $>$ Ftable, Ho is rejected. It concluded that there are differences in group learning outcomes using Interactive CD learning media and not using Interactive $C D$. It can be seen from the significance value is $0.028<$ significance 0.05 . The value showed the differences in learning outcomes of course participants who use both interactive $C D$ media and handout media on continental cake processing. 


\section{Discussion}

In the experimental class carried out by explaining the material about the meaning of continental cake, types of continental cakes, ingredients, tools, and processing methods by using interactive $C D$ media and video processing. The researchers explained and visualized the material through Macromedia flash media. Unlike the experimental class, conventional learning is carried out without using Macromedia flash media. Based on the pre-test results, it concluded that there is no significant difference between the control class and the experimental class. The hypothesis test results indicate that there are significant differences between the learning outcomes of participants in experimental class and control class. Fcount value is 5.513 , while the Ftable value is 2.27. Then Fcount> Ftable, Ho is rejected. It concluded that there are differences in group learning outcomes using Interactive CD learning media and not using Interactive CD. It can be seen from the significance value is $0.028<$ significance 0.05 . The value showed the differences in learning outcomes of course participants who use both interactive $C D$ media and handout media on continental cake processing. The result of $<\mathrm{g}\rangle$ value is 0.769 . It means that the learning outcomes improvement of continental cake processing in the experimental class by using interactive $C D$ media categorized as high. The learning outcomes in the control group by using media handouts amounted to 0.649 so that the assessment of improvement before and after using the media categorized as a medium.

According research, the pastry learning multimedia product are effective to improve student learning outcomes. It can be seen from the difference N-Gain scores that obtained by students at the pretest and post-test. The average increase of N-Gain is 0.72 with high criteria. It concluded that this pastry learning multimedia product is effective to improve learning outcomes in the Standards of Continental Cake Processing Competency and used for learning Vocational High School students in Pastry programs [11]. Effectiveness testing on the experimental group applied interactive CD media and videos about processing continental cakes shows $85 \%$ interval scale data with Effective scale. Whereas what is applied by conventional media in the form of handouts/PowerPoints and recipe sheets about processing continental cakes shows $70 \%$ interval scale data with an ineffective scale. Thus, the effectiveness of the use of treatment media in the form of interactive $C D$ media on processing continental cakes is increasing compared to the control class that uses conventional media. According the research, five media benefits in learning activities, namely; the delivery of subject matter 
can be uninformed, the learning process becomes more interesting, the learning process of students becomes more interactive, the amount of teaching and learning time reduced, the quality of student learning can be improved [14]. The learning outcomes delivered conclude that $70 \%$ of students 'learning outcomes in school are influenced by students' abilities, and 30\% are influenced by the environment. While one of the most dominant learning environments affecting learning outcomes in school is the quality of learning. The interactive continental CD cake media displays interesting visuals in the form of materials, images, sounds and videos of making continental cakes [15].

One effort to make it easier for students to receive teaching materials needs to endeavor so that students in learning use as many visual tools as possible. According to Edgar Dale in Arsyad, one's learning experience is $75 \%$ obtained from the eyes, $13 \%$ through the ears and the rest $12 \%$ through other senses [16]. While Baugh in Arsyad, suggests that $90 \%$ one's learning outcomes obtained from sight, only $5 \%$ obtained from hearing, and $5 \%$ is through other senses. Students are more enthusiastic and motivated to learn because they use a variety of interactive CD Multimedia and learning is not conventional because students learn independently using a computer. So, the advantage of this development research is to create a multimedia learning science that is packaged in the form of interactive CDs for elementary school students' fourth-grade learning activities, so that students get a different and more enjoyable learning atmosphere. These results illustrate that there is an increase in each cycle. The more appropriate interactive multimedia with the material, the more student learning outcomes [16]. Teachers who use CD-ROMs for learning media significantly help students' psychomotor and cognitive development and make it easier for students to understand learning material quickly. Fun learning will certainly also affect the level of learning outcomes obtained by these students because students will learn more than if the subject matter is presented only with a view stimulus or hearing stimulus [17]. Mahmudah's research supports the last theory that student learning activities increase when using multimedia so that student learning outcomes increase [18]. Similarly, Arianti said that use of multimedia successfully improves students' abilities, students can capture information better with the use of multimedia [19]. The provision of visual media for the learning of continental cake processing subjects can improve the learning quality of students. Learners more easily understand the material delivered by the instructor. It can be seen with the enthusiasm of the course participants following the material and practicum with interactive $C D$ media about continental cake processing. 


\section{Conclusion}

Based on the results of the study, the conclusions are; (1) The value of learning outcomes between using interactive $C D$ media is higher than conventional methods in the theory and practical processing of continental cake. (2) The improvement of learning outcomes is seen through the improvement of results before and after the application of interactive $C D$ media about processing continental cakes in the course participants. The results of the grades categorized as high. The increase in learning outcomes in the control group using media handouts categorized as a medium. (3) Effectiveness testing of the experimental group that applied interactive CD media and videos showed Effective scale. Whereas, effectiveness testing of the experimental group that applied handout media and videos showed ineffective scale.

\section{Funding}

This study was funded by the Applied Research Grant Program, Higher Education for the Institutional National Strategic Research Scheme for 2018 Fiscal Year.

\section{Acknowledgment}

The authors would like to thank the Indonesian Ministry of Research and Technology, the Institute of Research and Community Service of UNJ and Faculty of Engineering, State University of Jakarta for providing financial support to the research as well as some of the parties listed in the references in research results writing as a reference for previous theories and data research. Also, FT-UNJ as the organizer of 2018 ICTVET.

\section{Conflict of Interest}

The authors have no conflict of interest to declare.

\section{References}

[1] Klaus Scwhab. (2016). The Global Competitiveness Report 2016-2017. World Economic Forum. HIm. Xiii,29.

[2] Gabrilin, Abba. (2014). Anies Baswedan Sebut Pendidikan Indonesia Gawat Darurat. Diakses dari http://www.edukasi.kompas.com/read/2014/12/01/13455441/aniese. 
baswedan. sebut.pendidikan.indonesia.gawat.darurat pada tanggal 12 September 2018, Jam 06.14 WIB.

[3] PSDPK Kemendikbud. (2015). Statistika Pendidikan Nonformal Tahun 2014. PDSP Kementerian Pendidikan dan Kebudayaan. HIm. 1-157.

[4] Sugihartono, dkk. (2007). Psikologi Pendidikan. Yogyakarta: UNY Press.

[5] Ratna, E., Bundu, P. \& Tahmir, S. (2016). The Effect Of Emotional Intelligence, Competence And Interpersonal Communication On The Performance Of Senior High School Teachers Through Achievement Motivation In Makassar, Indonesia. New Educational Review. Vol 4 No 2.

[6] Rahayuningrum, R. H. (2012). Penggunaan Media Pembelajaran Multimedia Interaktif Berbantuan Komputer untuk Meningkatkan Motivasi Belajar dan Kemampuan Pemecahan Masalah Matematika Siswa Kelas VII-F di SMP Negeri 2 Imogiri Bantul. Makalah LSM XIX Lomba Seminar Matematika, ISBN: 978-979-17763-3-2. (Online), https://core.ac.uk/download/pdf/11064562.pdf), diakses 16 August 2018.

[7] Rasimin, S., Saputro. \& Musyahadah. (2012). Media Pembelajaran Teori dan Aplikasi. Yogyakarta: Trust Media Publishing.

[8] Eristi, S. D. (2010). The Effectiveness Of Interactive Instruction Cd Designed Through The Pre- School Students. Journal of Theoretical and Applied Information Technology, 2005 - 2008 JATIT, All rights reserved. www.jatit.org.

[9] Rahayuningrum, R. H. (2012). Penggunaan Media Pembelajaran Multimedia Interaktif Berbantuan Komputer untuk Meningkatkan Motivasi Belajar dan Kemampuan Pemecahan Masalah Matematika Siswa Kelas VII-F di SMP Negeri Imogiri Bantul. Makalah LSM XIX Lomba Seminar Matematika. ISBN: 978-979-17763-3-2. (Online), https://core.ac.uk/download/pdf/11064562.pdf), diakses 15 July 2018.

[10] Frey, B., \& Sutton, J. M. (2010). A Model for Developing Multimedia Learning Projects. MERLOT. Journal of Online Learning and Teaching Vol. 6, No. 2, Hal: 491-507. (online) http://creativecommons.org/licenses/by-nc-sa/3.0/us/), diakses 2 September 2018.

[11] Tri Sunarmi. (2015). Pengembangan Multimedia Pembelajaran Pastry Untuk Siswa Tingkat XI SMK. Jurnal Pendidikan Vokasi, Vol 5, Nomor 1, February 2015.

[12] Wiyanto. (2008). Menyiapkan Guru Sains Mengembangkan Kompetensi Laboratorium. Semarang: Unnes Press.

[13] Sugiyono. (2005). Metode Penelitian Bisnis. Bandung: Alfabeta.

[14] Yamin, Martinis. (2007). Profesionalisasi Guru \& Implementasi KTSP. Jakarta: Gaung Persada Press. 
[15] Clark, Richard E. (1983). Reconsidering Research on Learning from Media. Review of Educational Research is currently published by American Educational Research Association, Vol. 53, No. 4. (Winter, 1983), pp. 445-459.

[16] Arsyad, Azhar. (2006). Media Pembelajaran. Jakarta: PT. Rajagrafindo Persada.

[17] Kalburan, N. C. (2011). The use of CD-ROM in early childhood education: teacher's thoughts and practices. Pamukkale University. Journal Procedia Computer Science 3, Hal:1562-1570, (Online), Http://www.sciencedirect.com/science/article/ pii/S187705091100050), diakses 12 February 2018.

[18] Mahmudah, R. (2013). Peningkatan Hasil Belajar Siswa dengan Menggunakan Multimedia Berbasis Movie Maker di Sekolah Dasar. UNESA. E-Journal UNESA. Jurnal Penelitian Pendidikan Guru Sekolah Dasar, (Online), (http://ejournal.unesa.ac.id/index.php/jurnal-penelitianpgsd/article/view/3149/5380), diakses 22 June 2018.

[19] Arianti, Y, (2014). Penggunaan Multimedia Untuk Meningkatkan Kemampuan Menyimak Anak di Kelompok A PGTKIT Anak Cinta Islam Kecamatan Gayungan Kota Surabaya. E-Journal UNESA PAUD Teratai Vol 3, no 3, (2014), (online) http: //ejournal.unesa.ac.id/index.php/paud-teratai/article/view/7677/10390. Diakses 20 June 2018. 